\title{
Correction to: High-enthalpy hypersonic flows
}

Joseph J. S. Shang ${ }^{1 *}$ and Hong Yan ${ }^{2}$

The original article can be found online at https://doi.org/10.1186/ s42774-020-00041-y.

* Correspondence: joseph.shang@ wright.edu; josephjshang@gmail. com

The original article can be found online at https://doi.org/10.1186/ s42774-020-00041-y

${ }^{1}$ Wright State University, 3640 Colonel Glenn Highway, Dayton, $\mathrm{OH}$ 45435, USA

Full list of author information is available at the end of the article
Correction to: Adv Aerodyn 2, 19 (2020) https://doi.org/10.1186/s42774-020-00041-y

In the original publication of this article [1], the author indicated the Eq. (2-1) and Eq. (2-6) are not right.

The correct Equations are:

$$
\begin{aligned}
& \sum v_{i}^{\prime} N_{i} \rightleftarrows \sum v_{i}^{\prime \prime} N_{i} \\
& \dot{R}_{i}=k_{f, i}(T) \prod\left(\rho_{i} / M_{i}\right)^{v_{i}^{\prime}}-k_{b, i} \prod\left(\rho_{i} / M_{i}\right)^{v_{i}^{\prime \prime}}
\end{aligned}
$$

The publisher apologizes to the readers and authors for the inconvenience.

The original publication has been corrected.

\section{Author details}

${ }^{1}$ Wright State University, 3640 Colonel Glenn Highway, Dayton, OH 45435, USA. ${ }^{2}$ School of Power and Energy, Northwestern Polytechnical University, 127 West Youyi Road, Xi'an 710072, China.

Published online: 15 September 2020

\section{Reference}

1. Shang, Yan (2020) High-enthalpy hypersonic flows. Adv Aerodyn 2:19 https://doi.org/10.1186/s42774-020-00041-y original author(s) and the source, provide a link to the Creative Commons licence, and indicate if changes were made. The images or other third party material in this article are included in the article's Creative Commons licence, unless indicated otherwise in a credit line to the material. If material is not included in the article's Creative Commons licence and your intended use is not permitted by statutory regulation or exceeds the permitted use, you will need to obtain permission directly from the copyright holder. To view a copy of this licence, visit http://creativecommons.org/licenses/by/4.0/. 